\title{
OPEN The complex case of Macaronichnus trace fossil affecting rock porosity
}

\author{
Javier Dorador ${ }^{1 \bowtie}$, Francisco J. Rodríguez-Tovar ${ }^{2}$ \& Olmo Miguez-Salas ${ }^{2}$
}

Bioturbation is an important factor for reservoir quality due to the modification of host rock petrophysical properties (i.e., porosity, permeability, and connectivity). However, there is no predictable relationship between bioturbation and its effect on rock properties, due to the variability of the involved ichnological features. A detailed ichnological analysis is necessary to determine how bioturbation affects petrophysical properties in a bioturbated reservoir. Traditionally, ichnological features such as density, tiering, size, orientation, architecture, and fill, have been considered. However, other properties have been undervalued as is the case of lining. Here, we present a detailed study on the effects of Macaronichnus burrows, an ichnotaxon usually related to hydrocarbon exploration due to its high concentration in rock notably affecting petrophysical properties. Macaronichnus, a subhorizontal cylindrical burrow, is characterized by a well-defined and developed outer rim surrounding the tube core. Our data indicates a clear zonation in porosity according to burrow structure, with the lowest porosity in the tube core and higher values associated with the surrounded rim. This duality is determined by the tracemaker grain selective feeding activity and the consequent concentrated cementation. The organism concentrates the lighter minerals in the tube core fill during feeding, favoring post-depositional cementation during diagenesis and this results in lower porosity than the host rock. However, heavy minerals, mainly glauconite, are located in the rim, showing higher porosity. Our results support the view that ichnological analyses are essential to determine reservoir quality in bioturbated reservoirs, evidencing that other ichnological properties in addition to those traditionally considered must be evaluated.

Bioturbation is an important factor for reservoir quality estimation in the oil and gas industry. Biogenic activities may affect some petrophysical properties such as porosity, permeability, and connectivity ${ }^{1-3}$. This influence on rock properties can be either positive or negative (i.e., either increasing or decreasing porosity, respectively, in comparison to the host rock). Detailed ichnological analyses should be conducted in every bioturbated reservoir to quantify its effect and estimate the reservoir quality ${ }^{2,4}$. Traditionally, attention has been paid to particular characteristics of burrows impacting rock properties and reservoir quality such as density, tiering, size, orientation, architecture, fill, and lining ${ }^{2,5}$. With respect to lining, analyses have focused on its presence or absence ${ }^{6,7}$, and rarely on the petrophysical properties ${ }^{8,9}$. However, thickness and composition of the lining/mantle can be a major feature to be considered for some burrows, as is the case for Macaronichnus ${ }^{10}$.

Macaronichnus has been commonly associated with reservoir exploitation and then its effect has been analyzed in detail for some deposits ${ }^{1,9,11-13}$. Thus, Gingras et al. ${ }^{11}$ briefly pointed out that porosity distribution in sandstones dominated by Macaronichnus is complex and may affect the reservoir quality, but they suggest more research had to be done. Later, Gordon et al. ${ }^{13}$ analyzed the presence of Macaronichnus in the Bluesky Formation (Alberta, Canada) to determine that permeability was enhanced in those zones where Macaronichnus were abundant compared to similar non-bioturbated intervals. Then, Greene et al. ${ }^{8}$ pointed to differences between lining and filling, and Quaye et al. ${ }^{9}$ found that porosity and permeability in the burrow fill of Macaronichnus were higher than in the host sediment in the Funing Formation (Subei basin, China). These studies have shown the effect of Macaronichnus and its positive impact in spite of the general idea that bioturbation reduces permeability ${ }^{4}$. Moreover, Macaronichnus usually occurs in dense concentrations, commonly occupying more than $70 \%$ of the $\operatorname{rock}^{4}$, and it just takes very little time for producers (i.e., polychaetes) to do it ${ }^{14}$. At that concentration, it is an important biogenic structure affecting petrophysical properties, fluid flow, and, consequently, oil production. For all these reasons, we decided to analyze the effect of Macaronichnus in more detail.

Macaronichnus segregatis ${ }^{15}$ can be found from Permian to Holocene ${ }^{2}$, mostly in shallow foreshore and shallow subtidal deposits, but it has been also observed in deep-sea sediments such as shelf or slope deposits ${ }^{16-18}$. Macaronichnus is usually identified as non-branching, cylindrical, and sub-horizontal burrows from just a few 


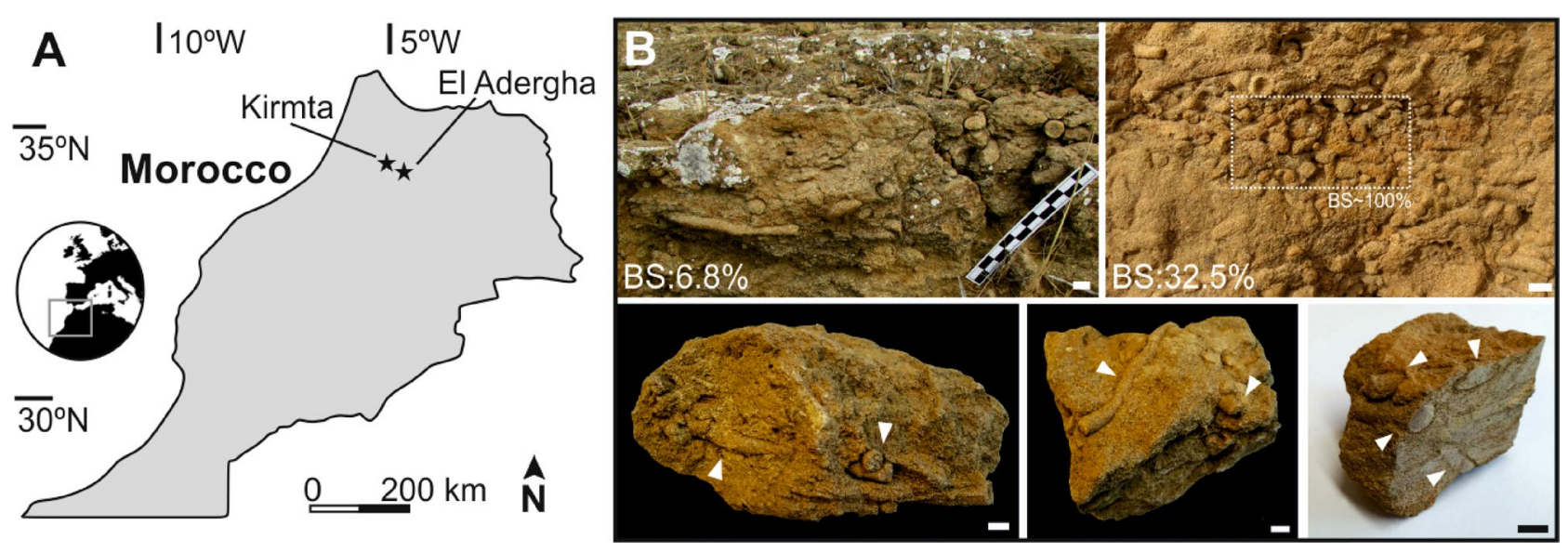

Figure 1. (A) Location map of the samples. (B) Outcrops and rock samples containing Macaronichnus with different bioturbation intensity and overlapping between them. White arrows point to Macaronichnus in rock samples. BS Bioturbated Surface. Scale bars $1 \mathrm{~cm}$.

\begin{tabular}{|c|c|c|c|c|c|c|c|c|c|c|c|c|c|c|c|}
\hline & Quartz & Feld & Mica & Glauc & Carb. R.F & Other R.F & $\begin{array}{l}\text { Argill. } \\
\text { matrix }\end{array}$ & Heavy min & Forams & $\begin{array}{l}\text { Other } \\
\text { biocl }\end{array}$ & $\begin{array}{l}\text { Calcite } \\
\text { cement }\end{array}$ & Dolom & \begin{tabular}{|l|} 
Iron ox./I \\
hydrox
\end{tabular} & Opaq & Por (\%) \\
\hline \multicolumn{16}{|c|}{ El Adergha } \\
\hline WS & 20.6 & 0.6 & 0.0 & 20.5 & 15.8 & 0.6 & 0.7 & 0.0 & 5.0 & 10.9 & 21.0 & 0.2 & 4.0 & 0.0 & 1.5 \\
\hline TC & 21.2 & 0.0 & 0.0 & 5.2 & 22.6 & 0.0 & 1.7 & 0.0 & 9.7 & 8.0 & 28.5 & 0.0 & 3.1 & 0.0 & 1.3 \\
\hline $\mathrm{R}$ & - & - & - & - & - & - & - & - & - & - & - & - & - & - & 3.0 \\
\hline HR & 19.0 & 0.7 & 0.0 & 18.3 & 15.8 & 0.7 & 1.1 & 0.0 & 6.5 & 9.7 & 23.7 & 0.7 & 3.6 & 0.4 & 1.5 \\
\hline \multicolumn{16}{|c|}{ Kirmta } \\
\hline WS & 15.1 & 0.0 & 0.0 & 22.5 & 20.6 & 0.0 & 1.1 & 0.0 & 3.4 & 15.6 & 9.6 & 0.2 & 11.9 & 0.2 & 1.6 \\
\hline TC & 23.0 & 0.0 & 0.0 & 2.7 & 18.7 & 0.7 & 0.0 & 0.0 & 5.7 & 12.3 & 26.0 & 1.3 & 9.3 & 0.3 & 0.0 \\
\hline $\mathrm{R}$ & 22.6 & 0.0 & 0.0 & 29.3 & 6.6 & 0.0 & 1.0 & Tr. & 1.7 & 18.1 & 13.2 & 0.0 & 7.0 & 0.3 & 5.3 \\
\hline HR & 17.5 & 0.0 & 0.0 & 18.9 & 21.6 & 0.0 & 0.0 & 0.0 & 2.1 & 13.4 & 16.5 & 0.3 & 9.3 & 0.3 & 2.4 \\
\hline
\end{tabular}

Table 1. Mean values of composition and porosity from analyzed samples considering the whole sample (WS), tube core (TC), rim (R) and host rock (HR). Tr. Traces, Feld. Feldspar, Glauc. Glauconite, Carb. Carbonates, R.F. Rock fragments, Argill. Argilliceous, Biocl. Bioclasts, Dolom. Dolomite, Opaq. Opaques, Por. Porosity.

millimeters up to $15 \mathrm{~mm}$ diameter, characterized by a clear mineralogical segregation between the cylinder tube core and the surrounding rim $^{15}$. Rim composition shows a concentration of darker and heavy minerals re-sorted by the producer during feeding, while lighter minerals commonly characterize the tube core ${ }^{2,11}$. This rim can be relatively thick, especially in the subichnospecies Macaronichnus segregatis degiberti ${ }^{16,17}$. However, the incidence of the rim on petrophysical properties has rarely been considered separately but as part of the entire infilling material (tube core and rim) ${ }^{9}$. Here, we analyze in detail the composition of infilling material from Macaronichnus segregatis degiberti differentiating between tube core and rim, focusing on its respective incidence on porosity and then on their particular impact in reservoir quality. This will help us to understand better the relative effect of every single part in porosity, which is essential to provide an accurate estimation of porosity in bioturbated reservoirs. For this study we investigate rock samples including specimens of Macaronichnus segregatis degiberti that were collected from two outcrops in northern Morocco: El Adergha $\left(34^{\circ} 4^{\prime} 34.19^{\prime \prime} \mathrm{N}, 4^{\circ} 51^{\prime} 33.43^{\prime \prime} \mathrm{W}\right)$ and Kir$\mathrm{mta}\left(34^{\circ} 10^{\prime} 15.07^{\prime \prime} \mathrm{N}, 5^{\circ} 14^{\prime} 21.43^{\prime \prime} \mathrm{W}\right)^{18-20}$ (Fig. 1A). These outcrops are interpreted as clastic contourite sandstones associated to the paleo-Mediterranean Outflow Water and the Rifian corridor that was connecting the Atlantic Ocean and the Mediterranean Sea during Late Miocene ${ }^{18-20}$. The outcrops belong to the South Rifian corridor (Saiss Basin) and are Late Miocene in age ${ }^{19-23}$. These locations were selected as sampling allows us to evaluate nice examples where Macaronichnus specimens are clearly identified with different degrees of bioturbation and overlapping between burrows (Fig. 1B).

\section{Results}

Petrographic analyses reveal that studied clastic contourites, defined as sandstones in the field, have similar proportions of clastic and carbonate components (Table 1). Strictly, they vary between bioclastic limestones and lithic sandstones, both with abundant glauconite. Carbonate clasts consist of bioclasts and some reworked carbonate rock fragments. Bioclasts are mainly bivalve fragments together with other fragments of foraminifera, echinoids, calcareous algae, and rarely bryozoa. Most bioclasts are rounded and clearly reworked. Quartz grains are abundant, feldspar and mica almost absent. Pellets of glauconite are abundant and recognized in all the samples; their 

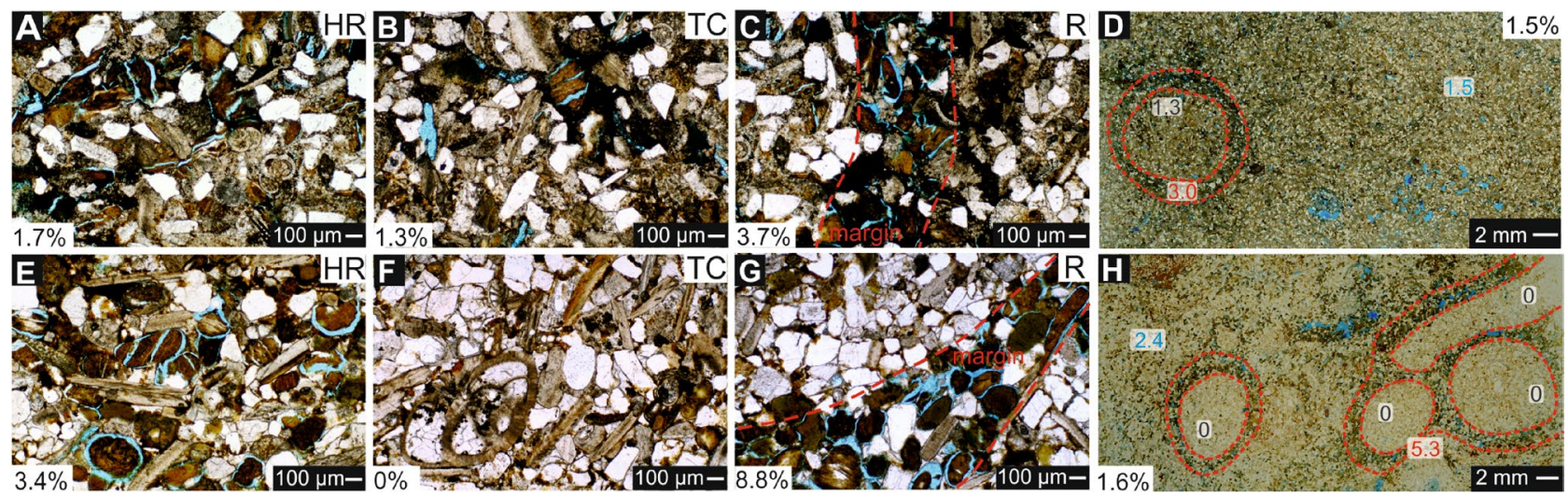

Figure 2. Close-ups from El Adergha (A-D) and Kirmta (E-H). (A,E) Close-ups from host rock (HR). (B,F) Tube cores (TC). (C,G) Rims (R). (D,H) Thin sections. Percentage values show the porosity in every case; in (C) and $(\mathbf{G})$ this is just referred to the rim. In thin sections $(\mathbf{D})$ and $(\mathbf{H})$, values measured in tube cores (black), rims (red), and host sediment (blue).

distribution is not random and is determined by burrow configuration (Fig. 2, Table 1). Glauconite is mainly concentrated in the rim of Macaronichnus burrows; meanwhile the tube core is mostly composed on carbonate components (i.e., carbonate rock fragments and calcite cement) and quartz (Fig. 2, Table 1). Visually, burrow rims are mostly defined by a marked concentration of glauconite pellets. Elongate clasts lie parallel to the margin.

When comparing the data of porosity from the whole sample (matrix and burrows) and the host rock (i.e., the matrix), which represent the primary porosity (Table 1$)$, values are slightly affected $(2.4 \%$ decreases to $1.6 \%$ in Fig. $2 \mathrm{H}$ ) or even remain unaltered (1.5\% in El Adergha; Fig. 2D). However, porosity is not homogeneously distributed and it is clearly determined by zonation of the burrows. Tube cores show lower values than host sediment in El Adergha (1.3\% vs 3.0\%), and they are being even completely non-porous in the case of Kirmta $(0.0 \%$ vs $5.3 \%)$. The highest porosity is located in rims, doubling values recorded in the host sediment in both cases and showing up to $8.8 \%$ porosity in some areas (Table 1, Fig. 2).

\section{Discussion}

It is well established that bioturbation may affect reservoir quality ${ }^{1-3,11,12,21}$. Previous studies have demonstrated that Macaronichnus is one of the trace fossils that can play an important role in bioturbated reservoirs ${ }^{9,11,13}$, generally having a positive impact. However, the previous studies mostly compared petrophysical properties from the host sediment and the entire burrow, without distinguishing between burrow tube core and outer rim. Our results demonstrate that the presence of Macaronichnus segregatis degiberti have, in general, a slightly negative impact on porosity, reducing values less than $1 \%$. However, going deeper, our data show a relevant fact, that is the marked difference between tube core and rim, not only in terms of composition, as is well-known, but also in porosity.

Regarding composition, the tube core is filled with light minerals that are highly cemented, and dark minerals, mainly glauconite, are concentrated in the rims. This compositional zonation is a diagnostic criterion for Macaronichnus ${ }^{15}$ and is determined by trace-makers during selective feeding activity ${ }^{11,15,17}$. In regards to porosity, a clear zonation is revealed. Mean porosity in the rims is two times higher than in the host sediment, reaching up to $8.8 \%$ porosity in some areas of the rock samples; however, porosity is very low in tube cores. This porosity zonation could be caused by original mineralogical heterogeneity combined with the associated post-depositional cementation ${ }^{1}$. During producer feeding activity, light minerals (mostly quartz and carbonates) are concentrated in the tube core and darker minerals (e.g., glauconite) are placed on the surrounded rim. This zonation causes the concentration of depositional cementation in the tube core. This concentrated cementation produced during diagenesis, generates a porosity zonation, which plays a determinant role in the effect on petrophysical properties. Then, tube cores are characterized by lower porosity values than the surrounded rims.

Gingras et al. ${ }^{11}$ reported that porosity distribution in Macaronichnus bioturbated sandstone is complex and acts like a dual porosity-permeability system. That means there would be a preferential flow through the burrows and a secondary flow from surrounding sediment into the burrows. Dual permeability systems are found in reservoirs where permeability contrast between matrix and burrows is high, around three orders of magnitude ${ }^{4}$. However, when permeability contrast is lower, a dual-porosity system is developed and there is not a preferential flow through the trace fossils ${ }^{4}$. Based on our results, this can be more complex for Macaronichnus as there is not a single flow system for the whole burrow due to the observed zonation. Petrophysical properties from tube core and rim are completely different and then both parts of the burrow should be considered separately when evaluating the effect on reservoir quality. Then, fluids would preferentially flow through the rim and, to identify the flow system, permeability contrast between host sediment and rim has to be evaluated. Macaronichnus burrow diameters have been reported from just a few millimeters ${ }^{11,14,22}$ to larger sizes up to $15 \mathrm{~mm}^{\text {diameter }}{ }^{16-18,23,24}$. However, most of the previous studies do not provide rim thick measurements. Savrda and Uddin ${ }^{10}$ recorded burrow tube cores and rim measurements and noted that tube core diameters ranged from 4 to $19 \mathrm{~mm}$ in large specimens. They reported that the rim thickness was variable along the burrow, ranging from about 1 to $5 \mathrm{~mm}$, being thicker at the bottom part of the burrow. This reveals that the rim occupies $25-30 \%$ of the volume of the 


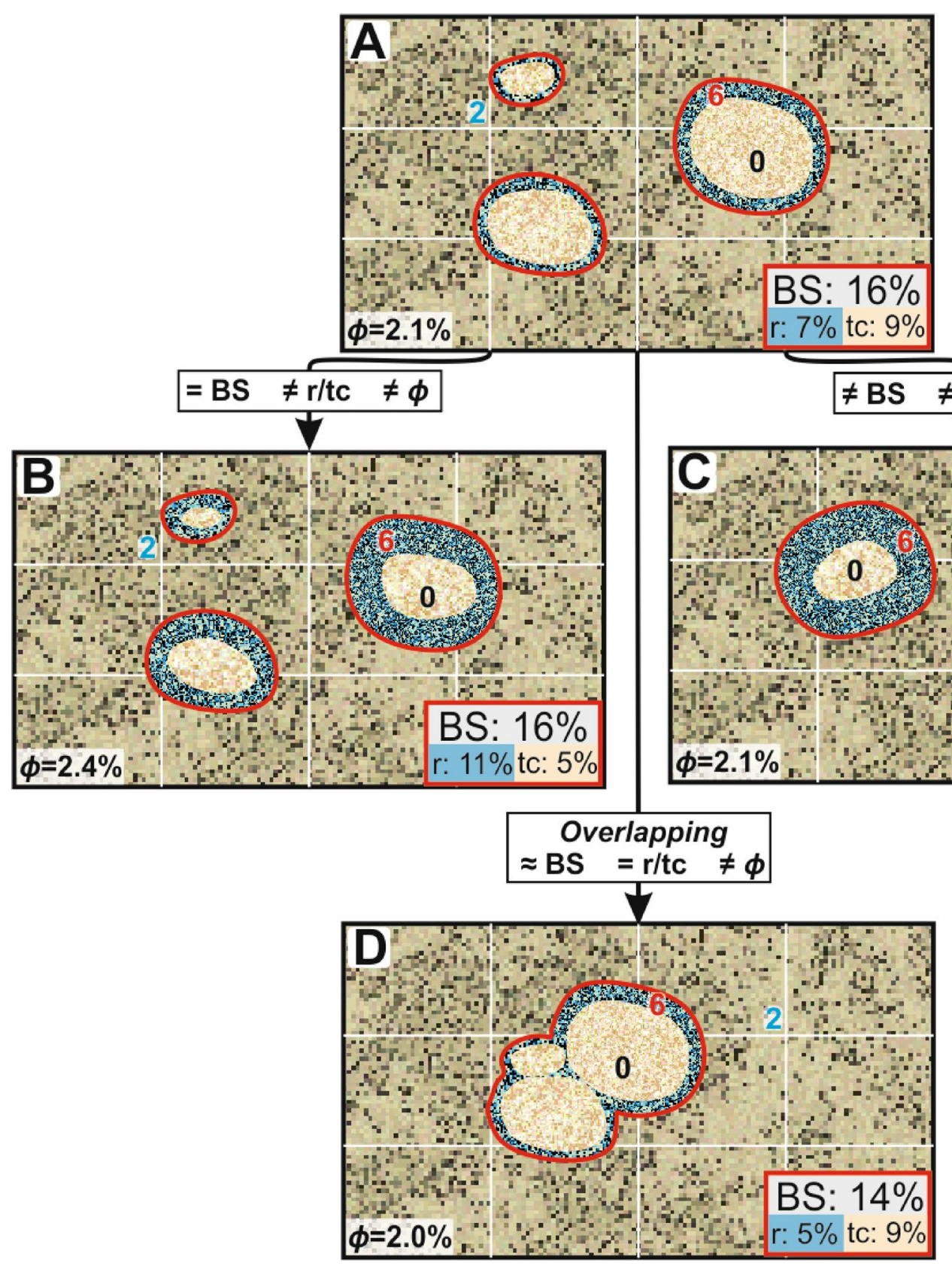

Figure 3. Theoretically modeled porosity effect by Macaronichnus. (A) Model scenario to be compared with $16 \%$ of bioturbated surface (BS) and porosity $(\phi) 2.1 \%$. (B) Situation with same BS, but different rim/tube core ratio $(\mathrm{r} / \mathrm{tc})$, causing an increase in $\phi$. (C) Scenario with same $\phi(2.1 \%)$ in spite of the lower BS, due to a higher $\mathrm{r} /$ tc. (D) Overlapped burrows with a very similar BS, but a decrease in rim surface due to crosscutting, reducing $\phi$. Bold numbers represent porosity from host sediment (blue), rim (red), and tube core (black).

burrows ${ }^{10}$. This fact can also be observed in some of the illustrated figures from previous papers. For example, Rodríguez-Tovar and Aguirre ${ }^{16}$ show large specimens of Macaronichnus segregatis degiberti with $\sim 15 \mathrm{~mm}$ diameter where rim was around $2-3 \mathrm{~mm}$ thickness, and Nara and Seike ${ }^{17}$ illustrated that the rim can be even thicker representing half the volume of the actual burrow (Fig. 3 from Nara and Seike ${ }^{17}$ ).

Therefore, rim thickness must not be underestimated, revealing as a key point to control Macaronichnus porosity effect. Especially considering that rim porosity can be two or three times higher than host sediment and represent an important volume portion of the whole burrow (up to 50\%). Assuming that Macaronichnus are frequently in dense concentrations, commonly representing more than $70 \%$ of bioturbation ${ }^{4}$, we can estimate that in some cases burrow rims can represent $35 \%$ of the total volume in a bioturbated sample.

Accordingly, to conduct a proper reservoir quality estimation in Macaronichnus-bearing rocks, porosities from both zones (rim and tube core) and their relative volumes need to be considered. Another aspect that needs to be considered is the frequent burrow crosscutting between specimens. Several theoretical situations involving 
different variables such as rim/tube core volume ratios, the degree of bioturbation and the overlapping between burrows are illustrated in Fig. 3, assuming porosity values of $2.0 \%, 0.0 \%$ and $6.0 \%$ in the host rock, rim, and tube core, respectively. We established a model scenario considering an example with $16 \%$ of bioturbated surface (BS) by isolated burrows, with a rim/tube core $(\mathrm{r} / \mathrm{tc})$ volume ratio of 0.77 and porosity $(\phi)$ of $2.1 \%$ of (Fig. $3 \mathrm{~A})$. We considered another scenario where burrows occupy the same surface but with thicker rim $(\mathrm{r} / \mathrm{tc}=2.2)$, which resulted in higher porosity $(\phi=2.4 \%)$ (Fig. 3B). Whereas in a less bioturbated example (Fig. 3C), we obtained the same porosity value compared to the model scenario $(\phi=2.1 \%)$ due to a higher $\mathrm{r} / \mathrm{tc}$ volume ratio $(\mathrm{r} / \mathrm{tc}=3.5)$. We simulated a final scenario with overlapped burrows (Fig. 3D) where the crosscutting of burrows resulted in a slightly lower surfaces value and $\mathrm{r} / \mathrm{tc}$ ratio which caused a small reduction of the porosity value compared to the model scenario $(\phi=2.0 \%)$. These four scenarios show how the relative $\mathrm{r} / \mathrm{tc}$ volume ratios and overlapping of burrows can affect the resulting porosity values. Although the results from these scenarios did not show significant changes in porosity values, but considering that Macaronichnus is commonly found representing more than $70 \%$ of rock volumes ${ }^{4}$, where rims could represent up to $50 \%$ of the burrows ${ }^{17}$ and overlapped, they could significantly modify the resulting porosity values of the host rock.

\section{Conclusions}

Macaronichnus has been shown to be a relevant trace fossil for reservoir quality in bioturbated deposits, mainly related to its occurrences as dense concentrations. This study has demonstrated that the porosity effect by Macaronichnus is not homogenous in the entire burrow and its distribution is clearly associated with the trace fossil structure. Porosity in the burrow tube core is different to that from the outer rim.

Producers of Macaronichnus generate a grain resorting during feeding when they concentrate carbonate components and quartz grains in the tube core fill, and heavy and darker minerals, mainly glauconite, in the rim. Regarding reservoir quality, results reveal that Macaronichnus is a complex case and has a dual behavior. Burrow rims have increased porosity with respect to the host sediment and provide positive effects. Fillings in tube cores have lower porosity and provide negative effects.

On this basis, the relative volume occupied by rims and tube cores should be determined to estimate the real effect of Macaronichnus on porosity. Any evaluation of the impact of Macaronichnus on petrophysical properties, and then on reservoir exploitation, based on just the intensity of bioturbation or the study of the whole burrow must induce significant misinterpretations of relevant scientific and economic implications. This complex dual behavior has been observed for the first time in Macaronichnus, but we could not discard that this could also be identified in some other trace fossils with marked internal zonation.

\section{Materials and methods}

Twenty-four rock samples of contourite sandstones including specimens of Macaronichnus segregatis degiberti were collected from two outcrops in northern Morocco: El Adergha $\left(34^{\circ} 4^{\prime} 34.19^{\prime \prime} \mathrm{N}, 4^{\circ} 51^{\prime} 33.43^{\prime \prime} \mathrm{W}\right)$ and Kirmta $\left(34^{\circ} 10^{\prime} 15.07^{\prime \prime} \mathrm{N}, 5^{\circ} 14^{\prime} 21.43^{\prime \prime} \mathrm{W}\right)^{18-20}$, (Fig. 1A). Ten samples were selected encompassing different degrees of bioturbation and variable overlapping between burrows (Fig. 1B). From the 10 samples, 30 thin sections containing Macaronichnus were prepared in the Department of Earth Sciences at Royal Holloway University of London and impregnated with blue dyed resin to highlight porosity. Struers EpoFix epoxy mixed with Sudan Blue II powder was used for the resin. Composition of all thin sections was described and eight of the thin sections, where Macaronichnus was better defined, were selected to conduct modal analyses. Host rock, tube core, and rim were differentiated for these analyses. Eleven quantitative modal analyses were conducted by determining the composition at 300 points on each thin section using a stepping stage and associated PETROG (Conwy Valley Systems Limited, UK), a software commonly used in quantitative petrography ${ }^{25,26}$, considering the largest intact rectangular area avoiding any marginal alteration. Mineral compositional analyses of tube cores and rims were undertaken by defining an elliptical area within these burrow parts. Rim modal analyses were not possible in samples from El Adergha due to rim size limitations. Porosity was also measured during modal analyses in host rock, tube core, and rim. Additionally, porosity from all the thin sections was also obtained by blue pixels counting using Photoshop ${ }^{27}$, obtaining a representative mean value for the whole samples and from every single part (i.e., host rock, tube core, and rim). Blue pixels were quantified using Color Range Selection Method $^{28}$. This method allows selecting all the blue pixels from an area of interest by clicking on some blue pixels and extending the selection to all the pixels with similar values. Once all the blue pixels are quantified, porosity can be calculated considering the number of pixels composing the area of interest. Intensity of bioturbation was quantified considering the bioturbated surface (BS), using Ichnological Digital Images Analysis Package (IDIAP) quantitative method ${ }^{28}$.

Theoretical scenarios were simulated considering different rim/tube core ratios, degree of bioturbation and overlapping between burrows (Fig. 3). For that, we selected some reasonable porosity values $(2.0 \%$ for host rock, $0.0 \%$ for rims and $6.0 \%$ for tube core burrows) based on thin sections observations. Resulting porosity was calculated using the selected porosity values for every zone considering the relative surface of every single part in every scenario.

\section{Data availability}

All data analysed during the present study are summarized in this published article. Analyzed thin sections are available under request.

Received: 7 October 2020; Accepted: 6 January 2021

Published online: 21 January 2021 


\section{References}

1. Pemberton, S. G. \& Gingras, M. K. Classification and characterizations of biogenically enhanced permeability. AAPG Bull. 89, 1493-1517 (2005).

2. Knaust, D. Atlas of Trace Fossils in Well Core (Springer, New York, 2017).

3. Eltom, H. A., Rankey, E. C., Hasiotis, S. T. \& Barati, R. Effect of bioturbation on petrophysical properties: Insights from geostatistical and flow simulation modeling. Mar. Pet. Geol. 104, 259-269 (2019).

4. Gingras, M. K. et al. Porosity and permeability in bioturbated sediments. In Trace Fossils as Indicators of Sedimentary Environments (eds Knaust, D. \& Bromley, R. G.) 837-868 (Elsevier, Amsterdam, 2012).

5. Knaust, D. Bioturbation and reservoir quality: towards a genetic approach. AAPG Annual Convention and Exhibition. Search and Discovery Article \#50900. (2013)

6. Pemberton, S. G. \& Frey, R. W. Trace fossils nomenclature and the Planolites-Palaeophycus dilemma. J. Palaeontol. 56, 843-881 (1982).

7. Pedersen, G. K. \& Bromley, R. G. Ophiomorpha irregulaire, rare trace fossil in shallow marine sandstones, Cretaceous Atane Formation, West Greenland. Cret. Res. 27, 964-972 (2006).

8. Greene, T. J., Gingras, M. K., Gordon, G. S. \& McKeel, D. R. The significance of deep-water cryptic bioturbation in slope-channel massive sand deposits of the lower Rio Dell Formation, El River basin, California. Mar. Pet. Geol. 29, 152-174 (2012).

9. Quaye, J. A., Jiang, Z. \& Zhou, X. Bioturbation influence on reservoir rock quality: A case study of Well Bian-5 from the second member Paleocene Funing Formation in the Jinhu sag, Subei basin, China. J. Pet. Eng. 172, 1165-1173 (2019).

10. Savrda, C. E. \& Uddin, A. Large Macaronichnus and their behavioral implications (Cretaceous Eutaw Formation, Alabama, USA). Ichnos 12, 1-9 (2005).

11. Gingras, M. K., MacMillan, B., Balcom, B. J., Saunders, T. \& Pemberton, S. G. Using magnetic resonance imaging and petrographic techniques to understand the textural attributes and porosity distribution in Macaronichnus-burrowed sandstone. J. Sed. Res. 72, 552-558 (2002).

12. Knaust, D. Ichnology as a tool in carbonate reservoir characterization: A case study from the permian: Triassic khuff formation in the middle east. GeoArabia 14, 17-38 (2009).

13. Gordon, J. B., Pemberton, S. G., Gingras, M. K. \& Konhauser, K. O. Biogenically enhanced permeability: A petrographic analysis of Macaronichnus segregatus in the lower cretaceous bluesky formation Alberta Canada. AAPG Bull. 94, 1779-1795 (2010).

14. Dafoe, L. T., Gingras, M. K. \& Pemberton, S. G. Determining euzonus mucronata burrowing rates with application to ancient Macaronichnus segregatis trace-makers. Ichnos 15, 78-90 (2008).

15. Clifton, H. E. \& Thompson, J. K. Macaronichnus Segregatis: A feeding structure of shallow marine polychaetes. J. Sed. Res. 48, 1-10 (1978).

16. Rodríguez-Tovar, F. J. \& Aguirre, J. Is Macaronichnus an exclusively small, horizontal and unbranched structure? Macaronichnus segregatis degiberti isubsp. nov.. Spanish J. Paleontol. 29, 131-142 (2014).

17. Nara, M. \& Seike, K. Palaeoecology of Macaronichnus segregatis degiberti: Reconstructing the infaunal lives of the travisiid polychaetes. Palaeogeogr. Palaeocl. Palaeoecol. 516, 284-294 (2019).

18. Miguez-Salas, O., Rodríguez-Tovar, F. J. \& De Weger, W. Macaronichnus and contourite depositional settings: Bottom currents and nutrients as coupling factors. Palaeogeog. Palaeocl. Palaeoecol. 545, 109639 (2020).

19. Capella, W. et al. Sandy contourite drift in the late Miocene Rifian Corridor (Morocco): Reconstruction of depositional environments in a foreland-basin seaway. Sed. Geol. 355, 31-57 (2017).

20. De Weger, W. et al. Late Miocene contourite channel system reveals intermittent overflow behavior. Geology 48, 1. https://doi. org/10.1130/G47944.1 (2020).

21. Knaust, D., Dorador, J. \& Rodríguez-Tovar, F. J. Burrowed matrix powering dual porosity systems: A case study from the Maastrichtian chalk of the Gullfaks Field, Norwegian North sea. Mar. Pet. Geol. 113, 104158 (2020).

22. Quiroz, L. I., Buatois, L. A., Gabriela Mángano, M., Jaramillo, C. A. \& Santiago, N. Is the trace fossil Macaronichnus an indicator of temperate to cold waters? Exploring the paradox of its occurrence in tropical coasts. Geology 38, 651-654 (2010).

23. Curran, H. A. The trace fossil assemblage of a Cretaceous nearshore environment: Englishtown Formation of Delaware, USA. in Biogenic Structures: Their Use in Interpreting Depositional Environments (ed. Curran, H.A.), 261-276 (1985).

24. Aguirre, J., de Gibert, J. M. \& Puga-Bernabéu, A. Proximal-distal ichnofabric changes in a siliciclastic shelf, Early Pliocene, Guadalquivir Basin, southwest Spain. Palaeogeog. Palaeocl. Palaeoecol. 291, 328-337 (2010).

25. Pantopoulos, G. \& Zelilidis, A. Petrographic and geochemical characteristics of Paleogene turbidite deposits in the southern Aegean (Karpathos Island, SE Greece): Implications for provenance and tectonic setting. Geochemistry 72, 153-166 (2012).

26. Carroll, E. L. \& Squires, K. E. Burning by numbers: A pilot study using quantitative petrography in the analysis of heat-induced alteration in burned bone. Int. J. Osteoarchaeol. 30, 691-699 (2020).

27. Zhang, X. et al. Adobe photoshop quantification (PSQ) rather than point-counting: A rapid and precise method for quantifying rock textural data and porosities. Comput. and Geosci. 69, 62-71 (2014).

28. Dorador, J., Rodríguez-Tovar, F. J. \& IODP Expedition 339 Scientists. Quantitative estimation of bioturbation based on digital image analysis. Mar. Geol. 349, 55-60 (2014).

\section{Acknowledgements}

The research by JD was funded through a EU's Horizon 2020 research and innovation program under the Marie Skłodowska-Curie Grant Agreement No. 792314 (ICON-SE). OM-S is funded through a pre-doctoral grant from the Ministerio de Educación, Cultura y Deporte, Spain. The present contribution was also funded by projects CGL2015-66835-P and PID2019-104625RB-100 (Secretaría de Estado de I+D+I, Spain), B-RNM-072-UGR18, P18-RT-4074 (Junta de Andalucía), and the Scientific Excellence Unit UCE-2016-05 (UGR). The research was conducted within the "The Drifters RG" (RHUL) and the "Ichnology and Palaeoenvironment RG" (UGR). We are most grateful for the constructive comments of two anonymous referees who helped us to improve the clarity of the manuscript.

\section{Author contributions}

J.D., F.J.R.-T. and O.M.-S. designed the idea, collected and selected the samples. J.D. coordinated the composition and conducted the porosity analysis. All the authors discussed the results, interpretations and contributed to the final version of the manuscript.

\section{Competing interests}

The authors declare no competing interests. 


\section{Additional information}

Correspondence and requests for materials should be addressed to J.D.

Reprints and permissions information is available at www.nature.com/reprints.

Publisher's note Springer Nature remains neutral with regard to jurisdictional claims in published maps and institutional affiliations.

(c) (i) Open Access This article is licensed under a Creative Commons Attribution 4.0 International License, which permits use, sharing, adaptation, distribution and reproduction in any medium or format, as long as you give appropriate credit to the original author(s) and the source, provide a link to the Creative Commons licence, and indicate if changes were made. The images or other third party material in this article are included in the article's Creative Commons licence, unless indicated otherwise in a credit line to the material. If material is not included in the article's Creative Commons licence and your intended use is not permitted by statutory regulation or exceeds the permitted use, you will need to obtain permission directly from the copyright holder. To view a copy of this licence, visit http://creativecommons.org/licenses/by/4.0/.

(C) The Author(s) 2021 